\title{
Frequency and impact of suboptimal immune recovery on first- line antiretroviral therapy within the International Epidemiologic Databases to Evaluate AIDS in East Africa
}

\author{
Damalie Nakanjako ${ }^{a, b}$, Agnes N. Kiraggaa ${ }^{a, b}$, Beverly S. Musick ${ }^{c}$, Constantin T. \\ Yiannoutsos $^{c, d}$, Kara Wools-Kaloustian ${ }^{e}$, Lameck Diero ${ }^{f}$, Patrick Oyarog, Emanuel Lugina ${ }^{h}$, \\ John C. Ssali', Andrew Kambugua ${ }^{a, b}$, and Philippa Easterbrook ${ }^{a}$ \\ anfectious Diseases Institute, Makerere University College of Health Sciences, Kampala, Uganda \\ ${ }^{b}$ Department of Medicine, Makerere University College of Health Sciences, Kampala, Uganda \\ 'Department of Biostatistics, Indiana University School of Medicine, Indianapolis, Indiana, USA \\ dDepartment of Biostatistics, Indiana University, RM Fairbanks School of Public Health, \\ Indianapolis, Indiana, USA eDepartment of Medicine at Indiana University School of Medicine, \\ Indianapolis, Indiana, USA ${ }^{\dagger}$ Academic Model Providing Access to Healthcare, Eldoret, kenya \\ gFamily AIDS, Care and Education Services, Kenya Medical Research Institute, Kisumu, Kenya \\ hOcean Road Cancer Institute, Dar es salaam, Tanzania, Kisumu iHIV Treatment Program, \\ Masaka Regional Referral Hospital, Masaka, Uganda
}

\section{Abstract}

Objective-To describe patterns of suboptimal immune recovery (SO-IR) and associated HIVrelated-illnesses during the first 5 years following first-line antiretroviral therapy (ART) initiation across seven ART sites in East Africa.

Design-Retrospective analysis of data from seven ART clinical sites (three Uganda, two Kenya and two Tanzania).

\begin{abstract}
Methods-SO-IR was described by proportions of ART-treated adults with $\mathrm{CD}^{+}$cell counts less than 200, less than 350 and less than 500 cells/ $\mu$. Kaplan-Meier survival analysis techniques were used to assess predictors of SO-IR, and incident rates of HIV-related illnesses at $\mathrm{CD}^{+}$cell counts less than 200, 200-350, 351-499, and >500 cells/ $\mu$, respectively.
\end{abstract}

Results-Overall 80843 adults initiated non-nucleoside reverse transcriptase inhibitor-based first-line ART; 65\% were women and median $\mathrm{CD}^{+}$cell count was 126 [interquartile range (IQR), $52-202]$ cells $/ \mu$ l. Cumulative probability of SO-IR $<200 \mathrm{cells} / \mu \mathrm{l},<350 \mathrm{cells} / \mu \mathrm{l}$ and $<500 \mathrm{cells} / \mu \mathrm{l}$,

Correspondence to Damalie Nakanjako, Infectious Diseases Institute, Makerere University College of Health Sciences, P.O. Box 22418, Kampala, Uganda.dnakanjako@gmail.com.

Authors' contributions: D.N., A.K., A.K.D., and P.E. made substantial contribution to the conception, design, and data interpretation. A.K. and C.Y. made substantial contribution to the data analysis. D.N. drafted the manuscript. A.K.D., L.D., P.O., E.L., J.C. made substantial contribution to data collection at the sites that contributed data. B.M., K.W. and C.Y. made substantial contribution to the compilation of the IeDEA dataset and analysis methods. All authors read and approved the final manuscript for publication.

Competing interests: The authors declare that they have no competing interests.

Conflicts of interest

The authors have no conflicts of interest. 
after 5 years, was 11,38 and $63 \%$, respectively. Incidence of HIV-related illnesses was higher among those with $\mathrm{CD} 4^{+}$cell counts less than 200 and 200-350 cells/ $\mu 1$, than those who achieved CD 4 counts above these thresholds. The most common events, at CD4 $<200$ cells $/ \mu$, were pulmonary tuberculosis [incident rate 15.98 (15.47-16.51)/100 person-years at risk (PYAR), oral candidiasis [incident rate $12.5(12.03-12.94)$ ] and herpes zoster [incident rate 6.30 (5.99-6.64)] events/100 PYAR. With attainment of a $\mathrm{CD}^{+}$cell count level 200-350 cells/ $\mu \mathrm{l}$, there was a substantial reduction in events/100 PYAR - by $91 \%$ to 1.45 (1.29-1.63) for TB, by $94 \%$ to 0.75 (0.64-0.89) for oral candidiasis, by $84 \%$ to $0.99(0.86-1.14)$ for Herpes Zoster, and by $78 \%$ to 1.22 (1.07-1.39) for chronic diarrhea. The incidence of all events decreased further with CD4 counts above these thresholds.

Conclusion-Around $40 \%$ of adults initiated on ART have suboptimal immune recovery with CD4 counts $<350$ cells $/ \mathrm{ml}$ after five years. Such patients will require closer monitoring for both HIV-related and non-HIV-related clinical events.

\section{Keywords}

cART; first-line antiretroviral therapy; HIV-related illnesses; immune recovery; Kenya; subSaharan Africa; Tanzania; Uganda

\section{Background}

The global scale up of antiretroviral therapy (ART) has shown remarkable progress during the last decade, with now more than 15 million individuals receiving ART [1,2]. The greatest increase has occurred in sub-Saharan Africa (SSA), where more than 11 million have received ART [2]. As of July 2014, ART has been associated with a 35\% decline in AIDSrelated mortality to approximately 1.7 million, compared with 2005 (and a 32\% decline in SSA), although the region still accounts for $70 \%$ of all persons dying from AIDS [1,2]. This has been made possible through adoption of a public health approach to treatment scale up, whereby the implementation of simplified and standardized approaches (such as simplified treatment regimens as part of fixed-dose combinations, and decentralization of services) ensures the widest possible access to high-quality services at the population level [3].

There has been a steady increase in the median $\mathrm{CD}^{+}$cell count at ART initiation in SSA [4,5], in accordance with successive WHO guidelines, less than 200 cells/ $\mu$ in 2006 [6], less than 350 cells/ $\mu$ in 2010 [7], less than 500 cells/ $\mu$ in 2013 [8], and now 'treat all' regardless of $\mathrm{CD}^{+}$cell count in 2015 [9]. However, late presentation and diagnosis remains common in many settings, and so ART is often initiated when disease is already advanced and CD4 ${ }^{+}$ cell counts are well below the recommended threshold. Late initiation of ART is associated with a high risk of early mortality, mainly due to HIV-related opportunistic infections especially in the first year before there has been sufficient time for adequate immune reconstitution, but also due to ART-related immune reconstitution inflammatory syndrome [10-12].

Although data on the distribution of the $\mathrm{CD} 4^{+}$cell count at ART initiation in adults is well documented in the literature [3,5,10], the subsequent CD4 response has been less well described, and in particular the proportion that remain profoundly immunosuppressed and at 
risk for opportunistic infections. Factors associated with sub-optimal immune recovery (SOIR) include older age [11-14], gender [15-18], advanced HIV disease at ART initiation [19], coinfections such as tuberculosis (TB) [20], hepatitis C [19] and persistent immune activation [13-15], and it is presumed to be mediated by severe HIV-associated immune dysfunction [21-23]. Even those who immune reconstitute to above 200 cells/ $\mu$ (the level above which they are at a substantially lower risk of opportunistic infections) but below 500 cells/ $\mu \mathrm{l}$ remain at risk for non-AIDS-defining events such as liver, cardiovascular and renal diseases [24], and other comorbidities due to persistent immune activation [24-27]. Moreover, a recent landmark the Strategic Timing of Anti-Retroviral Therapy trial (START) showed that starting ART when the $\mathrm{CD}^{+}$cell count is above 500 cells/ $\mu \mathrm{l}$ (compared with $<350$ cells $/ \mu \mathrm{l})$ more than halved the risk of AIDS events, deaths as well as serious non-AIDS events [28].

A range of definitions have been used to determine SO-IR at different time points after ART initiation. These include a magnitude of $\mathrm{CD}^{+}$cell count increase of less than $50 \mathrm{cells} / \mu \mathrm{l}$ after 6 months [29], or less than 100 cells/ $\mu$ after 12 months [12,30], and an absolute CD4 ${ }^{+}$ cell count remaining below 200 cells/ $\mu$ after 24 months [31,32], or below 500 cells $/ \mu$ after 60 months [33] as well as variations in longitudinal analyses [34]. Understanding the proportion of patients who fail to attain $\mathrm{CD}^{+}$cell count levels above 200, 350 and 500 cells/ $\mu \mathrm{l}$ has important programmatic implications. Those patients with SO-IR, and particularly $\mathrm{CD}^{+}$cell counts less than 200 cells $/ \mu \mathrm{l}$ will require closer monitoring for the development of AIDS-defining and non-AIDS-defining clinical events, as well as more prolonged prophylaxis (e.g. with cotrimoxazole and isoniazid). The objective of our analysis was threefold: first, to quantify the proportion with a CD4 ${ }^{+}$cell count below 200, 350 and 500 cells $/ \mu \mathrm{l}$ (reflecting the incremental WHO thresholds for ART initiation) during the first 5 years postART initiation; second, to describe clinical consequences of SO-IR and, third, to identify factors associated with suboptimal immune response.

\section{Methods}

\section{Study setting and participants}

The International epidemiologic Databases to Evaluate AIDS (IeDEA) network is an international research consortium, established in 2005 by the National Institute of Allergy and Infectious Diseases, that pools data from geographically dispersed cohorts to address regionally important epidemiological and HIV programmatic questions. Cohorts from all seven sites in the IeDEA East African region were included in this analysis, and dates of last available data or database closure are given in parentheses. These included three sites in Uganda, Mbarara Immune Suppression Syndrome Clinic (31 December 2009), Masaka Regional Hospital HIV Clinic (13 June 2011) and Infectious Diseases Institute, Makerere University (24 May 2011), two programs in western Kenya: Academic Model Providing Access to Healthcare (AMPATH) sites (27 July 2011) and Family AIDS Care and Education Services (FACES) sites (30 May 2011), and in Tanzania, Ocean Road Cancer Institute (ORCI) (14 July 2010), and Tumbi Special Hospital (18 September 2008). Analysis was conducted on de-identified data, and patients were not individually consented to participate. All research in IeDEA is overseen by institutional review boards or ethics committees in the 
countries where data are collected, and by ethics committees with oversight over the analytical teams $[4,5]$.

Within this region, we included all adult patients ( $\geq 18$ years at ART initiation) enrolled at one of the East Africa sites, who initiated an ART regimen that contained at least three drugs (according to the national HIV treatment guidelines), and had received at least 6 months of ART and remained in care. At the time, patients were initiated on stavudine, lamivudine/ zidovudine and nevirapine/efavirenz, with efavirenz given mainly for patients with TB and lamivudine for patients with hemoglobin levels below $8 \mathrm{~g} / \mathrm{dl}$; and one-drug regimen switches were recommended in cases of drug toxicities. Sociodemographic and clinical variables such as sex, age, ART regimen, and the dates of clinical events (ART initiation, follow-up visits and HIV-related illnesses including but not limited to oral and esophageal candidiasis, pulmonary TB, chronic diarrhea, herpes zoster eruptions, Kaposi's sarcoma, cryptococcal meningitis, Pneumocystis carinii pneumonia and papular pruritic eruptions), and CD4 measurements collected during the course of routine care (generally every 6 months) were available for analysis. Adherence support was provided routinely and patient adherence to ARTwas self-reported at $95 \%$ at least within the ART programs. Routine viral load monitoring was not available in the sites at the time of analysis.

\section{Data analysis}

Definition of suboptimal immune recovery-A variety of different definitions have been used in clinical trials [33,34], observational cohorts [31,32], pathogenesis studies $[19,35]$ to define suboptimal recovery. In this analysis, we defined SO-IR as failure to attain three different $\mathrm{CD} 4{ }^{+}$cell count thresholds during the first 5 years of first-line antiretroviral therapy: 200 cells/ $\mu \mathrm{l}$ (SO-IR200), below which individuals remain at particular risk of lifethreatening opportunistic infections [22,23]; 350 cells/ $\mu$ (SO-IR350) - the recommended threshold for ART initiation in the WHO 2010 guidelines [7] and 500 cells/ $\mu$ (SO-IR500) the recommended threshold for ART initiation in WHO 2013 guidelines [9]. CD4 ${ }^{+}$cell counts above 500 cells $/ \mu$ are considered normal relative to the average $\mathrm{CD} 4^{+}$cell counts of 2500 cells/ $\mu$ l among healthy Africans [36]. Baseline $\mathrm{CD} 4^{+}$cell count at ART initiation was defined as the most recent $\mathrm{CD} 4^{+}$cell count in the 2 months prior to ART initiation and a follow up $\mathrm{CD} 4^{+}$cell count was defined as the most recent $\mathrm{CD} 4^{+}$cell count within 2 months before and after the respective analysis time. Baseline variables at ART initiation included in the model were sex, age, BMI, WHO clinical stage, $\mathrm{CD}^{+}$cell count and ART regimen. Proportions of ART-treated patients in the three categories of SO-IR were calculated during the first 5 years of the ART programs.

Opportunistic infections and suboptimal immune recovery-Kaplan-Meier survival analysis techniques were used to assess the cumulative probability of suboptimal immune recovery, with competing risks of death or loss to followup. Using survival analysis, the incidence rates of HIV-related opportunistic infections and related illnesses during the first 5 years following ART initiation were obtained, and reported for the period (below the CD4 ${ }^{+}$cell count thresholds of 200, 200-350, 351-499 cells $/ \mu 1$ and $>500$ cells $/ \mu 1$. Individuals were censored at switch to second-line ART, death, loss to follow-up (defined as those with 
no clinic visit 6 months or more prior to database closure), database closure and at attainment of $\mathrm{CD}^{+}$cell counts 200-350 and 351-499 cells/ $\mu \mathrm{l}$ for the respective analyses.

The respective rates of HIV-related illnesses among these CD4 strata were expressed as incidence rates per 100 PYAR, with 95\% confidence intervals (CIs). Reductions in incidence rate (after attainment of the different CD4 thresholds) were expressed as percentage reductions. Predictors of SO-IR, using the three thresholds, were determined in a Cox proportion hazard model. Missing data on baseline $\mathrm{CD} 4^{+}$cell count were imputed using chained equations. All analysis was carried out using STATA 12 (Copyright 1985-2011. StataCorp LP, College Station, Texas, USA).

\section{Results}

\section{Patients eligible for inclusion in analysis of rate of suboptimal immune recovery}

Overall, 83926 initiated ART at the seven IeDEA sites in East Africa, of whom 3083 (3\%) were excluded because records showed that they had initiated less than three antiretroviral drugs. Each year, between 9 and 32\% of patients were lost to follow-up, with the highest numbers lost to follow-up in the first 3 years after ART initiation. Between 21 and $64 \%$ of the patients in care at each of the respective time points were not eligible for analysis of SOIR because they did not have a CD $4^{+}$cell count measurement at or within 2 months before and after the respective time point (Table 1).

\section{Patient characteristics at antiretroviral therapy initiation}

Of the 80843 patients initiating a triple antiretroviral drug regimen, $65 \%$ were women, and at ART initiation, the median age was 36 years; interquartile range (IQR) (30-43), BMI median was $20.1 \mathrm{~kg} / \mathrm{m}^{2}$ (IQR, 17.9- 22.5), median CD4+ cell count was 126 cells $/ \mu \mathrm{l}$ (IQR, 52-202), median hemoglobin was $11.3 \mathrm{~g} / \mathrm{dl}$ (IQR, 9.7- 12.9). The majority (97\%) initiated an non-nucleoside reverse transcriptase inhibitor-based regimen. Baseline demographic and clinical characteristics at ART initiation were similar across the three countries, but Tanzania had a low hemoglobin level: $9.6 \mathrm{~g} / \mathrm{dl}(7.9-11.4)$ versus $11.2 \mathrm{~g} / \mathrm{dl}(9.6-12.8)$ and $11.7 \mathrm{~g} / \mathrm{dl}$ (10.2-13.1) for Kenya and Uganda respectively, although the differences were not statistically significant (Table 2).

\section{Cumulative proportion with suboptimal immune recovery}

Overall, the proportions of ART-treated adults with SO-IR declined as absolute $\mathrm{CD}^{+}$cell counts increased over the duration of ART. The proportion with $\mathrm{CD}^{+}{ }^{+}$cell counts less than 200 cells/ $\mu \mathrm{l}$ reduced from $36 \%$ after 6 months of ART to $20 \%$ after 24 months and $11 \%$ after 60 months, and the proportion with a CD $4^{+}$cell count less than 350 cells/ $\mu \mathrm{l}$ reduced from $71 \%$ after 6 months of ART to 58\% after 24 months and 38\% after 60 months, and those with $\mathrm{CD}^{+}$cell counts less than 500 cells/ $\mu$ l reduced from $89 \%$ after 6 months of therapy to $80 \%$ after 24 months and $63 \%$ after 60 months of therapy (Table 3).

\section{HIV-related illnesses before and during immune recovery}

Using survival analysis techniques, we examined the cumulative probability of SO-IR [remaining with $\mathrm{CD}^{+}$cell count thresholds below 200 cells/ $\mu \mathrm{l}$ SO-IR200], between 200 and 
350 cells/ $\mu$ S SO-IR 350 and between 351 and 500 cells/ $\mu 1$ SO-IR 500 at each year during the first 5 years following ART initiation, taking into account the competing risks of death and loss to follow-up. Overall, there was 132356 PYAR with CD4 cells counts less than 200 cells $/ \mu \mathrm{l}, 127758$ PYAR >200 $\leq 350$ cells $/ \mu$ l, and 105823 PYAR > $350 \leq 500$ cells $/ \mu$ l.

The most common opportunistic infections prior to achieving $\mathrm{CD} 4^{+}$cell count threshold above 200 cells/ $\mu$ l were pulmonary TB [incident rate, per 100 person-years $(95 \% \mathrm{CI}), 15.98$ (15.47-16.51)] oral candidiasis [12.5 (12.03-12.94)], herpes zoster [6.30 (5.99-6.64)] and chronic diarrhea [5.48 (5.18-5.78)]. After attainment of a CD4 ${ }^{+}$cell count threshold above $200 \mathrm{cells} / \mu \mathrm{l}$ (between 200 and $350 \mathrm{cells} / \mu \mathrm{l}$ ), there was a substantial reduction in event rates of opportunistic infection events by $91 \%$ to $1.45(1.29-1.63)$ for TB, by $94 \%$ to $0.75(0.64-$ 0.89 ) for oral candidiasis, by $84 \%$ to $0.99(0.86-1.14)$ for herpes zoster, and by $78 \%$ to 1.22 (1.07-1.39) for chronic diarrhea (Table 4).

When the $\mathrm{CD} 4^{+}$cell count $>350<500$ cells $/ \mu$ strata was considered, pulmonary $\mathrm{TB}$, chronic diarrhea and pruritic purpura eruptions were the commonest HIV-related events at incident rates of $1.05(0.87-1.27), 1.08(0.89-1.31)$ and $1.11(0.92-1.34)$, respectively. After attainment of CD4 counts CD4 >500 cells/ $\mu$ l, AIDS related events such as pneumocystis carinii pneumonia, cryptococcal meningitis, extrapulmonary TB and toxoplasmosis were not observed (Table 4).

\section{Factors associated with suboptimal immune recovery}

In a multivariate analysis model we identified factors associated with SO-IR. Factors significantly associated with SO-IR200 were older age (every 5 year increase in age), subhazard ratio (SHR) [95\% CI, 1.01 (1.00-1.03), male gender, SHR 1.14 (1.08-1.20), baseline $\mathrm{CD} 4{ }^{+}$cell count less than 100 cells/ $\mu \mathrm{l}$ versus more than $100 \mathrm{cells} / \mu \mathrm{l}$, SHR $0.89(0.80-0.99)$, and hemoglobin level below $10 \mathrm{mg} / \mathrm{dl}$ versus $10 \mathrm{mg} / \mathrm{dl}$ and above, SHR 1.39 (1.29-1.48)], as shown in Table 5. The risk factors that were significant and magnitude of effect were similar across the different SO-IR CD4+ cell count thresholds of 200, 350 and 500 cells/ $\mu$ l. Baseline weight above $60 \mathrm{~kg}$ had a modest but statistically significant association with SO-IR 350 [SHR 1.04 (1.01-1.08)] and SO-IR 500 [SHR $1.05(1.02-1.07)]$.

\section{Discussion}

This analysis of around $80000 \mathrm{HIV}$-infected persons from HIV care programs in Kenya, Uganda and Tanzania who initiated mainly non-nucleoside reverse transcriptase inhibitorbased ART regimens between 2005 and 2011 at a median CD4+ cell count of 126 (52-202) cells/ $\mu$ l, represents the most comprehensive study of the frequency and consequences of suboptimal immune reconstitution to date. At 12 months, 29\% of ART-treated patients in care with follow-up $\mathrm{CD} 4^{+}$cell counts ( \pm within 2 months), had suboptimal immune recovery (SO-IR) with $\mathrm{CD}^{+}{ }^{+}$cell counts less than 200 cells/ $\mu 1,66 \%$ and $87 \%$ had SO-IR with CD4 ${ }^{+}$ cell counts below 350 and 500 cells/ $\mu 1$, respectively. Proportions of SO-IR declined with increasing duration of ART to $11 \%$ below 200 cells $/ \mu$ l, 38\% below 350 cells $/ \mu$ and $63 \%$ below 500 cells $/ \mu$, after 5 years of ART. 
SO-IR was associated with high rates of HIV-related opportunistic and other illnesses, and the commonest events were pulmonary TB, oral candidiasis and herpes zoster, followed by papular pruritic eruptions, chronic diarrhea, recurrent respiratory tract infections, esophageal candidiasis, Kaposi's sarcoma, chronic herpes simplex and pneumocystis pneumonia. In our current study, immune recovery to at least 200-350 cells/ $\mu$ l was associated with over $90 \%$ reduction in incidence of all opportunistic infections to an incidence rate of less than 1 per 100 person-years for all reported events except TB, chronic diarrhoea papular pruritic eruptions and respiratory tract infections. A similar pattern was observed for opportunistic infections in other $\mathrm{CD}^{+}$cell threshold categories. Although in a previous analysis from one of the clinic sites in Uganda, we reported comparable HIV-related events among optimal and suboptimal responders in the Infectious Diseases Institute (IDI) research cohort in Uganda, the latter study was based on only 380 persons with 123 events during a 2-year period of follow-up [31]. Therefore, using data from seven IeDEA sites, including IDI, substantially increased the statistical power to detect a higher incidence of opportunistic infections among SO-IR compared to optimal immune responders (OP-IR).

Other studies have shown similar rates of $\mathrm{CD}^{+}$cell counts persisting below 200 cells $/ \mu \mathrm{l}$, 350 and 500 cells/ $\mu 1$, and a continued high rate of clinical events during ART [32-34,37,38]. Even in settings where there is routine monitoring of viral load, data show that although the majority of those who are virologically suppressed achieve good immune recovery, up to $40 \%$ still exhibit SO-IR [39,40]. In the United Kingdom Collaborative HIV cohort study [34], ART-treated patients with CD4+ cell counts 350-499 cells/ $\mu \mathrm{l}$ had an opportunistic infection rate of 2.49 per 100 person-years, which was reduced to a rate of 1.54 per 100 person-years in those with a $\mathrm{CD} 4^{+}$cell count $500-649$ cell/ $\mu 1$ and 0.96 per 100 person-years among those with $\mathrm{CD}^{+}$cell counts above 650 cells/ $\mu$ l. In another multicenter study in Europe, ART-treated patient with suboptimal immune recovery (CD4 reported to gain of less than 50 cells after 1 year) had higher post-ART mortality of 3.22 per 100 person-years versus 0.71 per 100 person-years among optimal immune responders [41]. Similarly, among 850 participants in a community program in the United States during a 5-year follow up period, both AIDS and non-AIDS disease rates declined from 13.8 to 2.1 events per 100 person-years when the most recent CD4 cell count increased from less than 200 to 200 cells/ $\mu \mathrm{l}$ and from 2.0 to 1.7 events per 100 person-years when the latest $\mathrm{CD} 4^{+}$count increased from 200 to 350 cells/ $\mu$ to more than 350 cells/ $\mu \mathrm{l}$ [24].

We found that individuals with advanced HIV disease (WHO clinical stage 3 and 4, and $\mathrm{CD}^{+}{ }^{+}$cell count $<100$ cells/ $\mu$ l) were less likely to have SO-IR (SO-IR200, SO-IR350 and SO-IR500). This finding was similar to our previous report from IDI (one of the contributing sites) where pre-ART CD $4^{+}$cell count $\geq 100$ cells/ $\mu$ was associated with suboptimal immune recovery $\left(\mathrm{CD} 4^{+}\right.$cell count increase $<50$ cells/ $\mu$ after 6 months and $\mathrm{CD} 4^{+}$cell count increase $<200$ cells $/ \mu$ after 24 months of ART), when compared with individuals with preART CD4 ${ }^{+}$cell counts less than 100 cells/ $\mu$ [31]. Similarly, in the IDI cohort, individuals with pre-ART CD4 ${ }^{+}$cell counts of 50-199 cells/ $\mu$ l were three times more likely to have suboptimal immune recovery than those with pre-ART CD $4^{+}$cell counts less than 50 cells/ $\mu 1$ [31]. Our results are also consistent with previous reports from South Africa where individuals with pre-ART CD $4^{+}$cell counts less than 50 cells $/ \mu 1$ had better $\mathrm{CD} 4^{+}$cell count recovery during 48 weeks of ART compared to those with higher pre-ART CD4 ${ }^{+}$cell counts 
[11]. Additional evidence from three large HIV treatment programs in South Africa, showed that patients with pre-ART CD4 ${ }^{+}$cell counts less than 50 cells/ $\mu \mathrm{l}$ had a steeper gradient of $\mathrm{CD} 4^{+}$cell count increase than patients with pre-ART CD4 ${ }^{+}$cell counts between 50 and 199 cells $/ \mu 1$ [42]. The high $\mathrm{CD} 4^{+}$cell count recovery in these studies could be attributed to peripheral expansion and/or redistribution of CD4 $\mathrm{T}$ cells that is described in the initial phase of CD4 recovery during antiretroviral therapy [43]. Our findings are contrary to reports from the Australian HIV Observational database where higher baseline CD4 T-cell counts predicted attainment of a CD4 ${ }^{+}$cell count more than 500 cells/ $\mu 1$ [44].

Advanced HIV disease has been previously associated with high collagen deposition and irreversible fibrosis of the reticuloendothelial system, leading to poor immune recovery $[19,22,23]$. In addition, coinfections including hepatitis $C$ virus, genetic polymorphisms and differences in regulatory T-cell function and homeostasis have been suggested to contribute to poor CD4 T-cell recovery during ART [19]. We postulate that CD4 ${ }^{+}$cell counts may not be the best measure of immune recovery, particularly among individuals with advanced HIV disease in Africa. There is need to understand the role of other biomarkers of HIV disease progression, such as immune activation and microbial translocation markers [45], in enhancing the monitoring of immune recovery among individuals in SSA that initiate ART at advanced stages of disease. Measurement of HIV reservoir size could also provide additional evidence on response to ART, given the direct correlation of cell-associated HIV RNA with immune activation among ART-treated individuals [46].

Other factors with smaller impact on SO-IR were increased age (2-4\% increased risk for each 5-year increase in age), and weight more than $60 \mathrm{~kg}$. A less optimal immune response with increased age has also been reported in other studies, and among individuals older than 30 years of age [5,34], due to diminished thymus function with advancing age [5]. Similarly, other studies have reported an association between age greater than 30 years and poorer long-term immune response to ART [10,11], including an analysis of persons who had achieved viral suppression [8]. Patients with weight more than $60 \mathrm{~kg}$ at ART initiation were more likely to have SO-IR, although we were unable to use BMI due to incomplete height records. Previous reports from the North American AIDS Cohort Collaboration on Research and Design (NA-ACCORD) cohort suggest that a BMI of approximately $30 \mathrm{~kg} / \mathrm{m}^{2}$ at ART initiation was associated with greater CD4 T-cell recovery at 12 months compared with higher or lower BMI values, suggesting that body composition may affect peripheral CD4 Tcell recovery [47]. We therefore recommend consistent follow-up of BMI in African HIV treatment cohorts to further understand its role in host immune recovery during ART.

A key limitation and striking finding in this analysis of routinely collected data from 80000 persons, who initiated ART across multiple sites in East Africa, is that $21-64 \%$ of patients in care, depending on site, had no record of follow-up $\mathrm{CD}^{+}$cell count measurements at the different follow-up time points, and were therefore excluded from the analysis of suboptimal immune recovery. Although, we found no systematic differences in demographic or clinical characteristics of those with missing data, we speculate that these persons may be more likely to have suboptimal responses and therefore the true prevalence of suboptimal immune recovery may have been underestimated. This also highlights the real-world challenges of optimal data collection in resource-limited settings, and importance of strategies to optimize 
retention in care to achieve full impact of ART scale up. Second, there was no routine monitoring of viral load in our study population, so we were not able to describe underlying treatment failure and development of drug resistance as independent causes of SO-IR. This retrospective data analysis did not evaluate innate host factors that may contribute to slow immune recovery. Additional strategies of ART regimen optimization or immune modulatory interventions may require formal evaluation [48].

\section{What are the implications of these findings for antiretroviral programs?}

First, a high proportion (around 40\%) of patients initiated on ART in the absence of routine viral load monitoring did not achieve optimal immune recovery to at least a CD4 ${ }^{+}$cell count greater than 350 cells $/ \mu$ land remained at risk of HIV-related opportunistic and other infections. Such patients may require closer monitoring for the development of HIV-related as well as non-HIV-defining clinical events, and consideration for long-term prophylaxis with cotrimoxazole and isoniazid. There is now an increasing emphasis on strategic use of viral load monitoring rather than $\mathrm{CD} 4^{+}$cell count monitoring to assess response to ART and identify treatment failure early on, for individuals that require ART regimen switch to second-line ART $[9,32,37]$. Multiple studies have shown that when sustained viral suppression is achieved, there is good immune recovery [10,49]. Among 1004 patients ARTtreated patients attending the Melbourne Sexual Health Centre in Australia, routine CD4 ${ }^{+}$ cell counts rarely influenced clinical decisions to stop or change treatment therefore $\mathrm{CD} 4^{+}$ cell count monitoring was reduced from biannual to annual [50].

However, the significant proportion with SO-IR and ongoing HIV-related events in our cohort should caution ongoing discussions in countries about discontinuation of $\mathrm{CD}^{+}$cell count monitoring [45], particularly if patients have not attained $\mathrm{CD} 4^{+}$cell counts more than 500 cells $/ \mu$ l. Strategic monitoring of $\mathrm{CD}^{+}$cell count will be needed to identify those patients who remain at risk of opportunistic infections due to SO-IR based on readily available measures such as white blood cell count and lymphocyte percentage [44] or poor adherence $[20,43]$. Predictive models to identify those who will remain with a CD4 ${ }^{+}$cell count less than 200 cells/ $\mu$ in the first 3 years of therapy [44] could be used to prioritize $\mathrm{CD} 4^{+}$cell count and viral load measurements for those with SO-IR who may require adherence support or switch to second-line ART.

The database for these analyses did not include follow-up of patients that were not receiving ART. It is evident, however, that the opportunistic infections presented here could occur at higher $\mathrm{CD}^{+}{ }^{+}$cell counts, for example, $\mathrm{TB}$, oral candidiasis, and herpes zoster.

Our findings, emphasize the importance of earlier ART initiation as a priority to improve clinical outcomes since patients with SO-IR remain at risk of AIDS-related events. The Strategic Timing of Antiretroviral Treatment and TEMPRANO ANRS 12136 trials have demonstrated the profound impact of early ART at a CD $4^{+}$cell count above 500 cells $/ \mu \mathrm{l}$ compared to when the $\mathrm{CD} 4^{+}$cell count declines to below 350 cells/ $\mu 1$ [28,51], and international guidelines now recommend ART in all HIV infected persons regardless of $\mathrm{CD} 4^{+}$cell count $[9,52,53]$. However, even with continued progress of ART at any $\mathrm{CD} 4^{+}$cell count level in SSA [1,2], and the anticipated better immune recovery [4,33], some patients continue to initiate ART late and remain at greater risk of SO-IR. Given that all our patients 
initiated zidovudine/stavudine containing regimen (according to the ART guidelines and availability at the time), there is need to evaluate long-term immune recovery with the recommended newer drugs that are less toxic [1]. It is also important to note that these analyses were limited to patients on first-line therapy and did not provide data on CD4 trajectory after treatment switch to second-line therapy following immunological failure. Similarly, this study did not analyze the effects of one-drug regimen switches due to drug toxicities, given that adherence was not altered to levels below 95\%. Our results, however, remain important to ART programs in SSA since duration of first-line ART is an indicator of the success of ART programs, in addition to immunological/virological responses, survival, treatment adherence and retention in care [54].

\section{Conclusion}

Around $40 \%$ of ART-treated adults in East Africa had suboptimal immune recovery with CD4 counts $<350$ cells $/ \mu$ lafter the initial 5 years of first-line antiretroviral therapy, and this was associated with ongoing incident HIV-related illnesses. This has important programmatic implications, as these patients require closer monitoring for the development of HIV-related and non-HIV-related clinical events, as well as continued chemo-prophylaxis.

\section{Acknowledgements}

The authors acknowledge the staff of the Adult Infectious Disease Clinic for supporting the data collection and contributing data to IeDEA East Africa.

IeDEA East Africa: Participating sites - Samuel Ayaya, Lameck Diero, Edwin Sang, Elyne Rotich, AMPATH, Eldoret, Kenya; Elizabeth Bukusi, Medical Research Institute, Kisumu, Kenya; Geoffrey R. Somi, National AIDS Control Program, Dar es Salaam, Tanzania; Rita Lyamuya, Morogoro Regional Hospital, Morogoro, Tanzania; Edward Lugina, Ocean Road Cancer Institute, Dar es Salaam, Tanzania; Mark Urassa, Denna Michael Mkwasa, Kapella Ngonyani, National Institute for Medical Research, Dar es Salaam, Tanzania; Andrew Kambugu, Tumbi Regional Hospital, Kibaha, Tanzania; Philippa Easterbrook, Andrew Kambugu, Marion Achieng-Kariuki, Infectious Diseases Institute, Kampala, Uganda; Fred Nalugoda, Rakai Health Sciences Program, Kalisizo, Uganda; John Ssali, Masaka Regional Referral Hospital, Masaka, Uganda; Mwebesa Bosco Bwana, Winnie Muyindike, Mbarara University of Science and Technology, Mbarara, Uganda. Regional Data Centre: Constantin T. Yiannoutsos (principle investigator), Beverly S. Musick, Yee Yee H. Kuhn, Indiana University, Indianapolis, Indiana, USA. In addition, the authors acknowledge support from a Wellcome Trust Uganda doctoral and postdoctoral fellowships in Infection and Immunity held by Agnes Kiragga and Damalie Nakanjako respectively, funded by a Wellcome Trust Strategic Award, grant number 084344. Special acknowledgement goes to the study participants (IDI friends), staff and patients from the sites that contributed data; in Uganda, Mbarara and Masaka; in Kenya, Academic Model Providing Access to Healthcare (AMPATH) sites and Family AIDS Care and Education Services (FACES); and in Tanzania, Ocean Road Cancer Institute (ORCI).

\section{References}

1. WHO/UNAIDS. Global health sector response to HIV, 2000-2015: Focus on innovations in Africa: Progress report. World Health Organization; 2015. http://apps.who.int/iris/bitstream/ 10665/198148/1/WHO_HIV_2015.40_eng.pdf [Accessed April 11, 2016]

2. UNAIDS. UNAIDS Report Global Aids Epidemic. Geneva: UNAIDS; 2014. http://masteroon.com/ read/global-report-unaids-report-global-aids-epidemic-2014/ [Accessed 21 March 2016]

3. Gilks CF, Crowley S, Ekpini R, Gove S, Perriens J, Souteyrand Y, et al. The WHO public-health approach to antiretroviral treatment against HIV in resource-limited settings. Lancet. 2006; 368:505-510. [PubMed: 16890837]

4. Grimsrud A, Cornell M, Schomaker M, et al. CD4 count at antiretroviral therapy initiation and the risk of loss to follow-up: results from a multicentre cohort study. International Epidemiologic 
Databases to Evaluate AIDS Southern Africa Collaboration (IeDEA-SA). J Epidemiol Community Health. 2015; 10:136-147.

5. Egger M, Ekouevi DK, Williams C, Lyamuya RE, Mukumbi H, Braitstein P, et al. Cohort Profile: the international epidemiological databases to evaluate AIDS (IeDEA) in sub-Saharan Africa. Int J Epidemiol. 2012; 41:1256-1264. [PubMed: 21593078]

6. WHO. Guidelines for the use of antiretroviral agents in HIV-1-infected adults and adolescents. WHO/UNAIDS/UNICEF; 2006. http://www.aidsmap.com/WHO-guidelines/page/1730833/ [Accessed 4 July 2015]

7. WHO. Virologic and Immunological failure. Guidelines for the use of antiretroviral agents in HIV-1 infected adults and adolescents: Management of the treatment experienced patient. WHO/UNAIDS/ UNICEF; 2011. http://aidsinfo.nih.gov/Guidelines/HTML/1/adult-and-adolescent-treatmentguidelines/15/ [Accessed 8 April 2015]

8. WHO. Guidelines for the use of antiretroviral agents in HIV-1 infected adults and adolescents. Geneva: WHO; 2013. http://aidsinfo.nih.gov/contentfiles/lvguidelines/adultandadolescentgl.pdf [Accessed 21 March 2016]

9. WHO. Guidelines on when to start antiretroviral therapy and on preexposure prophylaxis for JIV. Geneva: WHO; 2015. http://www.who.int/hiv/pub/guidelines/earlyrelease-arv/en/ [Accessed on November 11, 2015]

10. Lewden C, Chene G, Morlat P, Raffi F, Dupon M, Dellamonica P, et al. HIV-infected adults with a CD4 cell count greater than 500 cells $/ \mathrm{mm}^{3}$ on long-term combination antiretroviral therapy reach same mortality rates as the general population. J Acquir Immune Defic Syndr. 2007; 46:72-77. [PubMed: 17621240]

11. Lawn SD, Myer L, Bekker LG, Wood R. CD4 cell count recovery among HIV-infected patients with very advanced immunodeficiency commencing antiretroviral treatment in sub-Saharan Africa. BMC Infect Dis. 2006; 6:59. [PubMed: 16551345]

12. Teixeira L, Valdez H, McCune JM, Koup RA, Badley AD, Hellerstein MK, et al. Poor CD4 T cell restoration after suppression of HIV-1 replication may reflect lower thymic function. AIDS. 2001; 15:1749-1756. [PubMed: 11579235]

13. Tiwari BR, Karki S, Ghimire P, Sharma B, Malla S. Improvement in immunological parameters in patients receiving highly active antiretroviral therapy in Nepal. Jpn J Infect Dis. 2013; 66:252-255. [PubMed: 23698491]

14. Aiuti F, Mezzaroma I. Failure to reconstitute CD4+ T-cells despite suppression of HIV replication under HAART. AIDS Rev. 2006; 8:88-97. [PubMed: 16848276]

15. Bastard M, Soulinphumy K, Phimmasone P, Saadani AH, Ciaffi L, Communier A, et al. Women experience a better longterm immune recovery and a better survival on HAART in Lao People's Democratic Republic. BMC Infect Dis. 2013; 13:27. [PubMed: 23339377]

16. Maman D, Pujades-Rodriguez M, Subtil F, Pinoges L, McGuire M, Ecochard R, et al. Gender differences in immune reconstitution: a multicentric cohort analysis in sub-Saharan Africa. PLoS One. 2012; 7:e31078. [PubMed: 22363550]

17. Maskew M, Brennan AT, Westreich D, McNamara L, MacPhail AP, Fox MP. Gender differences in mortality and CD4 count response among virally suppressed HIV-positive patients. J Womens Health (Larchmt). 2013; 22:113-120. [PubMed: 23350862]

18. Thorsteinsson K, Ladelund S, Jensen-Fangel S, Johansen IS, Katzenstein TL, Pedersen G, et al. Impact of gender on response to highly active antiretroviral therapy in HIV-1 infected patients: a nationwide population-based cohort study. BMC Infect Dis. 2012; 12:293. [PubMed: 23140254]

19. Gazzola L, Tincati C, Bellistri GM, Monforte A, Marchetti G. The absence of CD4+ T cell count recovery despite receipt of virologically suppressive highly active antiretroviral therapy: clinical risk, immunological gaps, and therapeutic options. Clin Infect Dis. 2009; 48:328-337. [PubMed: 19123868]

20. Hermans SM, Kiragga AN, Schaefer P, Kambugu A, Hoepelman AI, Manabe YC. Incident tuberculosis during antiretroviral therapy contributes to suboptimal immune reconstitution in a large urban HIV clinic in sub-Saharan Africa. PLoS One. 2010; 5:e10527. [PubMed: 20479873] 
21. Zeng M, Smith AJ, Wietgrefe SW, Southern PJ, Schacker TW, Reilly CS, et al. Cumulative mechanisms of lymphoid tissue fibrosis and T cell depletion in HIV-1 and SIV infections. J Clin Invest. 2011; 121:998-1008. [PubMed: 21393864]

22. Zeng M, Southern PJ, Reilly CS, Beilman GJ, Chipman JG, Schacker TW, et al. Lymphoid tissue damage in HIV-1 infection depletes naive T cells and limits $\mathrm{T}$ cell reconstitution after antiretroviral therapy. PLoS Pathog. 2012; 8:e1002437. [PubMed: 22241988]

23. Nakanjako D, Ssewanyana I, Nabatanzi R, Kiragga A, Kamya MR, Cao H, et al. Impaired T-cell proliferation among HAART-treated adults with suboptimal CD4 recovery in an African cohort. BMC Immunol. 2013; 14:26. [PubMed: 23786370]

24. Baker JV, Peng G, Rapkin J, Abrams DI, Silverberg MJ, MacArthur RD, et al. CD4+ count and risk of non-AIDS diseases following initial treatment for HIV infection. AIDS. 2008; 22:841-848. [PubMed: 18427202]

25. Mocroft A, Reiss P, Gasiorowski J, Ledergerber B, Kowalska J, Chiesi A, et al. Serious fatal and nonfatal non-AIDS-defining illnesses in Europe. J Acquir Immune Defic Syndr. 2010; 55:262270. [PubMed: 20700060]

26. Zoufaly A, Cozzi-Lepri A, Reekie J, Kirk O, Lundgren J, Reiss P, et al. Immuno-virological discordance and the risk of non-AIDS and AIDS events in a large observational cohort of HIVpatients in Europe. PLoS One. 2014; 9:1-10.

27. Zoufaly A, an der Heiden M, Kollan C, Bogner JR, Fätkenheuer G, Wasmuth JC, et al. Clinical outcome of HIV-infected patients with discordant virological and immunological response to antiretroviral therapy. J Infect Dis. 2011; 203:364-371. [PubMed: 21208929]

28. The INSIGHT START Study Group. Initiation of antiretroviral therapy in early asymptomatic HIV infection. N Engl J Med. 2015; 373:795-807. [PubMed: 26192873]

29. Tuboi SH, Brinkhof MW, Egger M, Stone RA, Braitstein P, Nash D, et al. Discordant responses to potent antiretroviral treatment in previously naive HIV-1-infected adults initiating treatment in resource-constrained countries: the antiretroviral therapy in low-income countries (ART-LINC) collaboration. J Acquir Immune Defic Syndr. 2007; 45:52-59. [PubMed: 17460471]

30. Florence E, Lundgren J, Dreezen C, Fisher M, Kirk O, Blaxhult A, et al. Factors associated with a reduced CD4 lymphocyte count response to HAART despite full viral suppression in the EuroSIDA study. HIV Med. 2003; 4:255-262. [PubMed: 12859325]

31. Nakanjako D, Kiragga A, Ibrahim F, Castelnuovo B, Kamya MR, Easterbrook PJ. Sub-optimal CD4 reconstitution despite viral suppression in an urban cohort on antiretroviral therapy (ART) in sub-Saharan Africa: frequency and clinical significance. AIDS Res Ther. 2008; 5:23. [PubMed: 18957083]

32. Ahn JY, Boettiger D, Law M, Kumarasamy N, Yunihastuti E, Chaiwarith R, et al. Effects of CD4 monitoring frequency on clinical endpoints in clinically stable HIV-infected patients with viral suppression. J Acquir Immune Defic Syndr. 2015; 69:85-92. [PubMed: 25622062]

33. Kaufmann GR, Furrer H, Ledergerber B, Perrin L, Opravil M, Vernazza P, et al. Characteristics, determinants, and clinical relevance of CD4 T cell recovery to $<500$ cells/microL in HIV type 1 infected individuals receiving potent antiretroviral therapy. Clin Infect Dis. 2005; 41:361-372. [PubMed: 16007534]

34. Phillips AN, Gazzard B, Gilson R, Easterbrook P, Johnson M, Walsh J, et al. Rate of AIDS diseases or death in HIV-infected antiretroviral therapy-naive individuals with high CD4 cell count. AIDS. 2007; 21:1717-1721. [PubMed: 17690569]

35. Hunt PW, Cao HL, Muzoora C, Ssewanyana I, Bennett J, Emenyonu N, et al. Impact of CD8+ Tcell activation on CD4+ T-cell recovery and mortality in HIV-infected Ugandans initiating antiretroviral therapy. AIDS. 2011; 25:2123-2131. [PubMed: 21881481]

36. Lugada ES, Mermin J, Kaharuza F, Ulvestad E, Were W, Langeland N, et al. Population-based hematologic and immunologic reference values for a healthy Ugandan population. Clin Diagn Lab Immunol. 2004; 11:29-34. [PubMed: 14715541]

37. Gale HB, Gitterman SR, Hoffman HJ, Gordin FM, Benator DA, Labriola AM, et al. Is frequent CD4+ T-lymphocyte count monitoring necessary for persons with counts $>=300$ cells $/ \mu \mathrm{l}$ and HIV-1 suppression? Clin Infect Dis. 2013; 56:1340-1343. [PubMed: 23315315] 
38. Nicastri E, Chiesi A, Angeletti C, Sarmati L, Palmisano L, Geraci A, et al. Clinical outcome after 4 years follow-up of HIV-seropositive subjects with incomplete virologic or immunologic response to HAART. J Med Virol. 2005; 76:153-160. [PubMed: 15834865]

39. Battegay M, Nuesch R, Hirschel B, Kaufmann GR. Immunological recovery and antiretroviral therapy in HIV-1 infection. Lancet Infect Dis. 2006; 6:280-287. [PubMed: 16631548]

40. Maggiolo F, Leone S. CD4+ T lymphocyte recovery in individuals with type 1 human immunodeficiency virus infection. Clin Infect Dis. 2010; 51:465-467. [PubMed: 20597689]

41. Gutierrez F, Padilla S, Masia M, Iribarren JA, Moreno S, Viciana P, et al. Patients' characteristics and clinical implications of suboptimal CD4 T-cell gains after 1 year of successful antiretroviral therapy. Curr HIV Res. 2008; 6:100-107. [PubMed: 18336257]

42. Schomaker M, Egger M, Maskew M, Garone D, Prozesky H, Hoffmann CJ, et al. Immune recovery after starting ART in HIV-infected patients presenting and not presenting with tuberculosis in South Africa. J Acquir Immune Defic Syndr. 2013; 63:142-145. [PubMed: 23364513]

43. Rajasuriar R, Gouillou M, Spelman T, Read T, Hoy J, Law M, et al. Clinical predictors of immune reconstitution following combination antiretroviral therapy in patients from the Australian HIV Observational Database. PLoS One. 2011; 6:1-10.

44. Badolato R. Immunological nonresponse to highly active antiretroviral therapy in HIV-infected subjects: is the bone marrow impairment causing CD4 lymphopenia? Clin Infect Dis. 2008; 46:1911-1912. [PubMed: 18462176]

45. Chow EP, Read TR, Chen MY, Fehler G, Bradshaw CS, Fairley CK. Routine CD4 cell count monitoring seldom contributes to clinical decision-making on antiretroviral therapy in virologically suppressed HIV-infected patients. HIV Med. 2015; 16:196-200. [PubMed: 25236189]

46. Hatano H, Jain V, Hunt PW, Lee TH, Sinclair E, Do TD, et al. Cell-based measures of viral persistence are associated with immune activation and programmed cell death protein 1 (PD-1)expressing CD4+ T cells. J Infect Dis. 2013; 208:50-56. [PubMed: 23089590]

47. Koethe JR, Jenkins CA, Lau B, Shepherd BE, Silverberg MJ, Brown TT, et al. Body mass index and early CD4 T-cell recovery among adults initiating antiretroviral therapy in North America, 1998-2010. HIV Med. 2015; 16:572-577. [PubMed: 25960080]

48. Rajasuriar R, Khoury G, Kamarulzaman A, French MA, Cameron PU, Lewin SR. Persistent immune activation in chronic HIV infection: do any interventions work? AIDS. 2013; 27:11991208. [PubMed: 23324661]

49. Porter K, Walker S, Hill T, Anderson J, Leen C, Johnson M, et al. Changes in outcome of persons initiating highly active antiretroviral therapy at a CD4 count less than 50 cells $/ \mathrm{mm} 3$. J Acquir Immune Defic Syndr. 2008; 47:202-205. [PubMed: 17971709]

50. Chow EP, Read TR, Chen MY, Fehler G, Bradshaw CS, Fairley CK. Routine CD4 cell count monitoring seldom contributes to clinical decision-making on antiretroviral therapy in virologically suppressed HIV-infected patients. HIV Med. 2015; 16:196-200. [PubMed: 25236189]

51. The TEMPRANO ANRS 12136 Study Group. A trial of early antiretrovirals and isoniazid preventive therapy in Africa. N Engl J Med. 2015; 373:808-822. [PubMed: 26193126]

52. British HIV Association Writing group. Guidelines for the treatment of HIV-1-positive adults with antiretroviral therapy 2012 (Updated November 2013). HIV Med. 2014; 15(Suppl 1):1-85.

53. Panel on Antiretroviral HHS Guidelines for Adults and Adolescents. Guidelines for the use of antiretroviral agents in HIV-1-infected adults and adolescents. Department of Health and Human Services; http://www.aidsinfo.nih.gov/ContentFiles/AdultandAdolescentGL [Accessed 21 March 2016]

54. Boulle A, Bock P, Osler M, Cohen K, Channing L, Hilderbrand K, et al. Antiretroviral therapy and early mortality in South Africa. Bull World Health Organ. 2008; 86:678-687. [PubMed: 18797643] 
Table 1

Cohort description of antiretroviral therapy-treated adults eligible for inclusion in analysis for 60 months of follow-up after antiretroviral therapy initiation.

\begin{tabular}{|c|c|c|c|c|c|}
\hline \multirow[b]{2}{*}{ Follow-up time (months) } & \multicolumn{5}{|c|}{83926 initiated ART (of whom 3083 with less than drugs were excluded) } \\
\hline & $\begin{array}{l}\text { In care } \\
n(\%)\end{array}$ & $\begin{array}{l}\mathbf{L T F U}^{a} \\
n(\%)\end{array}$ & $\begin{array}{c}\text { In care without a } \mathrm{CD4}^{+} \\
\text {cell count } \\
\boldsymbol{b} \\
n(\%)\end{array}$ & $\begin{array}{c}\text { In care with } \mathrm{CD4}^{+} \text {cell } \\
\text { count }^{c} \\
n(\%)\end{array}$ & $\begin{array}{c}\text { In care with pre-ART } \\
\mathrm{CD4}^{+} \text {and follow-up CD4 } 4^{+} \\
\text {cell count } \\
n(\%)\end{array}$ \\
\hline 0 & 80843 & & & & \\
\hline 6 & $65930(82)$ & $14913(18)$ & $13851(21)$ & $29050(44)$ & $23029(35)$ \\
\hline 12 & $54923(68)$ & $25920(32)$ & $15316(28)$ & $22347(41)$ & $17260(31)$ \\
\hline 24 & $39547(49)$ & $15376(19)$ & $15257(39)$ & $14058(36)$ & $10232(26)$ \\
\hline 36 & $26675(33)$ & $12872(16)$ & $16192(61)$ & $6037(23)$ & $4446(17)$ \\
\hline 48 & $18322(23)$ & $8353(10)$ & $13245(72)$ & $2024(11)$ & $3053(17)$ \\
\hline 60 & $10423(13)$ & $7899(9)$ & $6712(64)$ & $2149(21)$ & $1562(15)$ \\
\hline \multicolumn{6}{|c|}{ ART, antiretroviral therapy; LTFU, loss to follow-up. } \\
\hline \multicolumn{6}{|c|}{$\begin{array}{l}\text { a LTFU (individuals who have not had a clinic visit for } 6 \text { months and were excluded from the analyses) the percentage is among all patients initiated } \\
\text { on three-drug first-line ART regimen. }\end{array}$} \\
\hline \multicolumn{6}{|c|}{$\begin{array}{l}b_{\text {Patients in care without a } \mathrm{CD} 4}{ }^{+} \text {cell count within } 2 \text { months of time point, excluded from the analyses. The percentage is among all patients in care } \\
\text { at each time point. }\end{array}$} \\
\hline
\end{tabular}


Table 2

\section{Characteristics at antiretroviral therapy initiation in 80843 patients across seven} programmes in Kenya, Uganda and Tanzania.

\begin{tabular}{|c|c|c|c|c|}
\hline Baseline characteristics & Overall $n=80843$ & $\begin{array}{c}\text { Kenya } 2 \text { programmes } n \\
=61109\end{array}$ & $\begin{array}{c}\text { Uganda } 3 \text { programmes } n \\
=17793\end{array}$ & $\begin{array}{c}\text { Tanzania } 2 \\
\text { programmes } n=1941\end{array}$ \\
\hline Female, $n(\%)^{a}$ & $52158(64.5)$ & $39299(64.3)$ & 10978 (61.6) & $1251(64.5)$ \\
\hline $\begin{array}{l}\text { Age in years, median } \\
\text { (IQR) }\end{array}$ & $36(30-43)$ & $36(30-43)$ & $35(29-41)$ & $38(32-45)$ \\
\hline $\begin{array}{l}\text { BMI }\left(\mathrm{kg} / \mathrm{m}^{2}\right) \text {, median } \\
(\mathrm{IQR})\end{array}$ & $20.1(17.9-22.5)$ & $19.9(17.9-22.3)$ & $20.8(18.5-23.4)$ & $21.5(21.2-23.8)$ \\
\hline $\begin{array}{l}\text { Hemoglobin level (g/dl); } \\
\text { median (IQR) }\end{array}$ & $11.3(9.7-12.9)$ & $11.2(9.6-12.8)$ & $11.7(10.2-13.1)$ & $9.6(7.9-11.4)$ \\
\hline $\begin{array}{l}\mathrm{CD} 4^{+} \text {cell count }(\text { cells } / \mu \mathrm{l}) \\
\text { median (IQR) }\end{array}$ & $126(52-202)$ & $130(56-208)$ & $111(39-187)$ & $113(44-188)$ \\
\hline Prior ART use for PMTCT & $b_{299 / 50} 277$ (0.6) & $219 / 39299(0.6)$ & $80 / 10978(0.7)$ & $\mathrm{n} / \mathrm{a}$ \\
\hline \multicolumn{5}{|l|}{ First-line ART regimen } \\
\hline $\begin{array}{l}\text { NNRTI-based regimen } c \text {; } \\
n(\%)\end{array}$ & $d_{78106(96.6)}$ & $58833(96.3)$ & $17332(97.4)$ & $1941(100)$ \\
\hline PI-based regimen & $2051(2.5)$ & $1770(2.9)$ & $281(1.6)$ & \\
\hline Triple NRTI & $322(0.4)$ & $147(0.2)$ & $175(0.98)$ & \\
\hline Others ${ }^{e}$ & $364(0.5)$ & $359(0.6)$ & $5(0.03)$ & \\
\hline
\end{tabular}

Sites in Kenya were Academic Model Providing Access to Healthcare (AMPATH) and Family AIDS Care and Education Services (FACES) sites, Uganda sites were Mbarara Immune Suppression Syndrome Clinic, Masaka Regional Hospital HIV Clinic and Infectious Diseases Institute, Makerere University, and Tanzania sites were Ocean Road Cancer Institute (ORCI) and Tumbi Special Hospital. ART, antiretroviral therapy; IQR, interquartile range; NNRTI, non-nucleoside reverse transcriptase inhibitor; NRTI, nucleoside reverse transcriptase inhibitor; PI, protease inhibitor; PMTCT, prevention of mother to child transmission.

${ }_{13}$ missing gender.

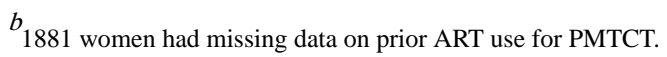

${ }^{c}$ NNRTI-based regimen included all efavienz [16 $888(21.6 \%)$ ] and nevirapine-containing regimens [61 $\left.622(78.9 \%)\right]$. All patients initiated zidovudine/stavudine containing regimen that were recommended and available at the time.

$d_{404 \text { had three-drug regimen with both nevirapine and efavirenz. }}$

$e^{e}$ Others includes individuals with ART regimen containing more than active antiretroviral drugs (excluding those with boosted lopinavir). 
Table 3

Suboptimal immune recovery during the first 5 years of antiretroviral therapy at seven sites in East Africa.

\begin{tabular}{|c|c|c|c|c|}
\hline Months of follow-up & $\begin{array}{l}\text { Number in care } \\
\text { with CD4 } 4^{+} \text {cell } \\
\text { counts }\end{array}$ & $\begin{array}{c}\text { Number and proportion } \\
\text { with SO-IR < 200 cells/ } \mu \mathrm{l} n \\
(\%)\end{array}$ & $\begin{array}{c}\text { Number and proportion } \\
\text { with SO-IR <350 cells/ } \mu \mathrm{I} n \\
(\%)\end{array}$ & $\begin{array}{c}\text { Number and proportion } \\
\text { with SO-IR }<500 \text { cells } / \mu \mathrm{l} n \\
(\%)\end{array}$ \\
\hline 6 & 29050 & $10355(36)$ & $20689(71)$ & $25907(89)$ \\
\hline 12 & 22347 & $6376(29)$ & $14684(66)$ & $19369(87)$ \\
\hline 24 & 14058 & $2803(20)$ & $7699(58)$ & $11213(80)$ \\
\hline 36 & 6037 & $978(16)$ & $2851(47)$ & $4471(74)$ \\
\hline 48 & 4024 & $578(14)$ & $1685(42)$ & $2721(68)$ \\
\hline 60 & 2149 & $235(11)$ & $813(38)$ & $1355(63)$ \\
\hline
\end{tabular}

SO-IR, suboptimal immune recovery. 
Table 4

Rates of HIV-related illnesses in four CD4 cell count strata during the first 5 years of first line antiretroviral therapy.

\begin{tabular}{|c|c|c|c|c|}
\hline Type of HIV-related illness & $\begin{array}{l}\text { CD4 }<200 \text { cells } / \mu \text { Rate } \\
\text { per } 100 \text { PYAR }(95 \% \text { CI })\end{array}$ & $\begin{array}{c}\text { CD4 200-350 cells/ } \mu \mathrm{I} \\
\text { Rate per 100PYAR } \\
(95 \% \text { CI })\end{array}$ & $\begin{array}{c}\text { CD4 351-500 cells/ } \mu \mathrm{l} \\
\text { Rate per 100PYAR } \\
(95 \% \text { CI })\end{array}$ & $\begin{array}{c}\text { CD4 }>500 \text { cells } / \mu \mathrm{l} \\
\text { Rate per 100PYAR } \\
(95 \% \mathrm{CI})\end{array}$ \\
\hline Pulmonary TB & $15.98(15.47-16.51)$ & $1.45(1.29-1.63)$ & $1.05(0.87-1.27)$ & $0.98(0.87-1.10)$ \\
\hline Oral candidiasis & $12.5(12.03-12.94)$ & $0.75(0.64-0.89)$ & $0.61(0.47-0.78)$ & $0.60(0.54-0.72)$ \\
\hline Herpes Zoster & $6.30(5.99-6.64)$ & $0.99(0.86-1.14)$ & $0.84(0.68-1.04)$ & $0.60(0.52-0.71)$ \\
\hline Chronic diarrhoea & $5.48(5.18-5.78)$ & $1.22(1.07-1.39)$ & $1.08(0.89-1.31)$ & $0.84(0.71-0.91)$ \\
\hline Esophageal candidiasis & $1.98(1.81-2.17)$ & $0.20(0.15-0.28)$ & $0.14(0.08-0.23)$ & $0.15(0.13-0.23)$ \\
\hline Kaposi Sarcoma & $1.82(1.66-2.01)$ & $0.30(0.23-0.39)$ & $0.18(0.11-0.28)$ & $0.13(0.09-0.18)$ \\
\hline Pneumocystis carinii pneumonia & $1.86(1.69-2.04)$ & $0.30(0.23-0.39)$ & $0.14(0.08-0.23)$ & - \\
\hline Cryptococcal meningitis & $1.06(0.93-1.20)$ & $0.38(0.30-0.47)$ & $0.28(0.19-0.40)$ & - \\
\hline Herpes Simplex Virus & $1.43(1.28-1.59)$ & $0.32(0.25-0.42)$ & $0.18(0.11-0.28)$ & $0.18(0.13-0.24)$ \\
\hline Extrapulmonary TB & $1.12(1.00-1.27)$ & $0.30(0.23-0.39)$ & $0.28(0.19-0.40)$ & - \\
\hline Toxoplasmosis & $0.51(0.42-0.61)$ & $0.09(0.06-0.15)$ & $0.04(0.02-0.12)$ & - \\
\hline Pruritic purpura eruptions & $3.33(3.13-3.54)$ & $1.61(1.44-1.27)$ & $1.11(0.92-1.34)$ & $0.97(0.86-1.09)$ \\
\hline Recurrent URTI & $2.56(2.39-2.74)$ & $1.11(0.97-1.27)$ & $0.82(0.66-1.01)$ & $1.00(0.89-1.13)$ \\
\hline
\end{tabular}

TB, tuberculosis, URTI, Upper respiratory tract infection. 
Table 5

Multivariate analysis of factors associated with suboptimal immune recovery among adults receiving first-line antiretroviral therapy at seven sites in East Africa.

\begin{tabular}{|c|c|c|c|c|c|c|}
\hline \multirow[b]{3}{*}{ Patient factors } & \multirow{2}{*}{\multicolumn{2}{|c|}{$\begin{array}{c}\mathrm{CD4}^{+} \text {cell count }(\mathrm{SO}-\mathrm{IR} 200)<200 \\
\text { cells/ } \mu \mathrm{l}\end{array}$}} & \multirow{2}{*}{\multicolumn{2}{|c|}{$\begin{array}{c}\mathrm{CD4}^{+} \text {cell count }<350 \text { cells } / \mu \mathrm{l} \\
(N=52762) \\
\end{array}$}} & \multirow{2}{*}{\multicolumn{2}{|c|}{$\begin{array}{c}\mathrm{CD4}^{+} \text {cell count }<500 \text { cells/ } \mu \mathrm{l} \\
(N=54895) \\
\end{array}$}} \\
\hline & & & & & & \\
\hline & $\begin{array}{c}\text { Sub-hazard ratio }(95 \% \\
\text { CI) }\end{array}$ & $P$ & $\begin{array}{c}\text { Sub-hazard ratio }(95 \% \\
\text { CI) }\end{array}$ & $P$ & $\begin{array}{l}\text { Sub-hazard ratio }(95 \% \\
\text { CI) }\end{array}$ & $P$ \\
\hline Age per 5-year increase & $1.01(1.00-1.03)$ & 0.026 & $1.04(1.03-1.05)$ & $<0.001$ & $1.04(1.03-1.05)$ & $<0.001$ \\
\hline Male gender & $1.14(1.08-1.20)$ & $<0.001$ & $1.09(1.05-1.12)$ & $<0.001$ & $1.03(1.00-1.05)$ & 0.035 \\
\hline \multicolumn{7}{|c|}{ Baseline $\mathrm{CD} 4^{+}$cell count $(\text {cells } / \mu \mathrm{l})^{a}$} \\
\hline$<100$ & $0.89(0.80-0.99)$ & $<0.001$ & $0.72(0.68-0.74)$ & $<0.001$ & $0.74(0.71-0.76)$ & $<0.001$ \\
\hline $100-200$ & 1.00 & & $0.68(0.65-0.71)$ & $<0.001$ & $0.65(0.63-0.67)$ & $<0.001$ \\
\hline$\geq 200$ & & & 1.00 & & 1.00 & \\
\hline \multicolumn{7}{|l|}{ WHO clinical stage } \\
\hline I-II & 1.00 & $<0.001$ & 1.00 & $<0.001$ & 1.00 & $<0.001$ \\
\hline III-IV & $0.79(0.74-0.83)$ & & $0.72(0.70-0.74$ & & $0.73(0.71-0.75)$ & \\
\hline \multicolumn{7}{|l|}{ First-line cART regimen } \\
\hline Triple-NRTI & $0.83(0.66-1.04)$ & 0.104 & $0.72(0.62-0.82)$ & $<0.001$ & $0.73(0.66-0.81)$ & $<0.001$ \\
\hline PI-based & $0.68(0.39-1.19)$ & 0.176 & $0.79(0.59-1.06)$ & 0.117 & $0.86(0.71-1.05)$ & 0.148 \\
\hline NNRTI-based & 1.00 & & 1.00 & & 1.00 & \\
\hline \multicolumn{7}{|c|}{ Baseline hemoglobin count (g/dl) } \\
\hline$<10$ & $1.39(1.29-1.48)$ & $<0.001$ & $1.29(1.24-1.34)$ & $<0.001$ & $1.29(1.26-1.33)$ & $<0.001$ \\
\hline$\geq 10$ & 1.00 & & 1.00 & & 1.00 & \\
\hline \multicolumn{7}{|l|}{ Baseline weight $(\mathrm{kg})$} \\
\hline$<60$ & 1.00 & 0.181 & 1.00 & 0.008 & 1.00 & $<0.001$ \\
\hline$\checkmark 60$ & $1.04(0.98-1.10)$ & & $1.04(1.01-1.08)$ & & $1.05(1.02-1.07)$ & \\
\hline
\end{tabular}

NNRTI, non-nucleoside reverse transcriptase inhibitor; NRTI, nucleoside reverse transcriptase inhibitor; PI, protease inhibitors; antiretroviral therapy (ART).

${ }^{a}$ The reference group for SO-IR200 is $\mathrm{CD}^{+}{ }^{+}$cell count $100-200$ cells/ $/$ l. 